Jean-Philippe Robé*

\title{
The Shareholder Value Mess (And How to Clean it Up)
}

https://doi.org/10.1515/ael-2019-0039

Abstract: Shareholder Value is not only a myth, as forcefully demonstrated by Lynn Stout. It has also led to a mess under the form of extensive negative externalities and growing inequalities. A different measure of value creation is urgently required.

Keywords: shareholder value, accounting, negative externalities, firm

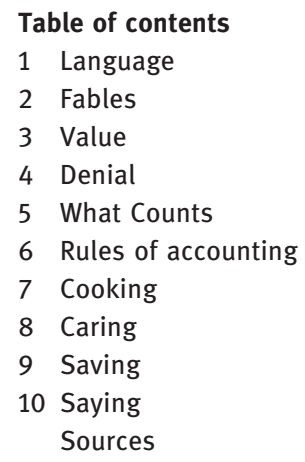

The Corporate Issue: A Tribute to Lynn Stout

1. Why Lynn Stout Took Up the Sword Against Share Value Maximization, by Margaret Blair, https://doi.org/10.1515/ael-2020-0083.

2. Beating Shareholder Activism at Its Own Game, by Margaret Blair, https://doi.org/10.1515/ ael-2019-0040.

3. Ownership (Lost) and Corporate Control: An Enterprise Entity Perspective, by Yuri Biondi, https://doi.org/10.1515/ael-2019-0025.

4. The Shareholder Value Mess, by Jean-Philippe Robé, https://doi.org/10.1515/ael-2019-0039.

5. Executive Pay and Labor's Shares: Unions and Corporate Governance from Enron to DoddFrank, by Sanford M. Jacoby, https://doi.org/10.1515/ael-2019-0073.

The author of this article has benefited from the comments of Yuri Biondi, Margaret M. Blair, Benoît Fleury, Anastasia Nesvetailova, John F. Olson, Ronen Palan, Hannah Petersen and Richard Phillips. The usual caveat applies.

*Corresponding author: Jean-Philippe Robé, Ecole de droit de Sciences Po, Paris, France, E-mail: jrobe@gibsondunn.com

(C) 2020 CONVIVIUM, association loi de 1901 
6. How America's Corporations Lost Their Public Purpose, and How it Might be (Partially) Restored, by David Ciepley, https://doi.org/10.1515/ael-2019-0088.

7. The Contest on Corporate Purpose: Why Lynn Stout was Right and Milton Friedman was Wrong, by Thomas Clarke, https://doi.org/10.1515/ael-2020-0145.

8. Lynn Stout, Pro-sociality, and the Campaign for Corporate Enlightenment, by Donald Langevoort, https://doi.org/10.1515/ael-2020-0067.

Lynn Stout stands up and declares: " shareholder value is a myth! » ${ }^{1}$

«Yes, but it has created quite a mess » answers her friend. « And now, we have to clean it up. »

\section{Language}

There is a widespread confusion in the literature on economic organizations between the concept of « corporation » and the concept of « firm ». The two words are often used interchangeably, " company » or " enterprise » being also sometimes used as synonyms. This confusion exists in the general language as well, of course. But it is only the source of mild misunderstandings of little consequences in everyday life. In the social sciences dealing with the economy and its organization, the confusion is extremely damaging.

The firm (or enterprise - I use the two words as synonyms) ${ }^{2}$ is an organization performing an economic activity: it is coordinating via the firm management the contributions of various resource providers to the firm's operations. Via the firm's processes, offices, plants, pieces of machinery, equipment, computers, software, trademarks, logarithms, employees, distributors, and so on are set in motion and organized. Through these processes, goods are produced or services are delivered. The firm is not a legal person; it is an organization of resource providers. ${ }^{3}$ It effectively operates as an organization in the social, economic, legal and political systems without being a legal person. It owns nothing; it signs no contract; it is not legally responsible for anything. It is not subject to accounting rules and provides no accounting of its activities to the public.

The corporation is a totally different concept: the corporation is a specific legal device designed to concentrate equity capital and it is a legal person which can be used to legally structure activities, including firms. If a firm can be created without having recourse to a corporation (by a single individual entrepreneur, or

1 Lynn A. Stout, The Shareholder Value Myth - How Putting Shareholders First Harms Investors, Corporations and the Public, San Francisco: BK Business Books (2012), pp. 23-25.

2 See generally Jean-Philippe Robé, The Legal Structure of the Firm, Accounting, Economics, and Law: Vol. 1: Issue 1, Article 5, Available at: https://doi.org/10.2202/2152-2820.1001 (2011).

3 See generally Jean-Philippe Robé, supra, note 4. 
by a partnership, for example), virtually all large business firms requiring the use of substantial amounts of financial capital are legally structured using one or several corporations. There are technical reasons explaining why a corporation is a superior legal vehicle to concentrate equity capital and being used to structure large firms. They mostly relate to the partitioning of assets and liabilities, and of the decision-making authority, among the corporation, the directors and officers, and the shareholders. ${ }^{4}$

Lynn Stout was in agreement that " the careless but unfortunately common habit of treating them as synonyms confuses and misleads. ${ }^{5}$ With such a confusion between firms and corporations, productive organizations are treated as being merely " nexuses of contract » whose existence does not particularly affect the economic analysis of the operation of a market economy. Using loose language, economists consider that shareholders own firms/corporations [they own shares issued by corporations], that the corporate officers and directors are the shareholders' agents [they are agents of the corporation] and that officers and directors have a duty to maximize short-term shareholder value [no such duty exists at law]. As agents, firm managers are deemed to only have a maximizing function in the name of their principals: the shareholders. The more " shareholder value » they create, the better for the shareholders and society as a whole.

As written in 2012 by the 1991 economics Nobel prize Ronald Coase:

The degree to which economics is isolated from the ordinary business life is extraordinary and unfortunate. ...

It requires an intricate web of social institutions to coordinate the working of markets and firms across various boundaries. At a time when the modern economy is becoming increasingly institutions-intensive, the reduction of economics to price theory is troubling enough. ... Knowledge will come only if economics can be reoriented to ... the economic system as it actually exists. ${ }^{6}$

In the " economic system as it actually exists », firms have to be differentiated from corporations. This is how knowledge will come. One major issue with the reduction of productive organizations to markets and contracts is an inappropriate accounting of the outcome of firm management. Being a legal person with an economic activity, a corporation is subject to accounting rules and must provide the public

4 For a review, see generally Jean-Philippe Robé, Being Done with Milton Friedman, Accounting, Economics, and Law: Vol. 2: Iss. 2, Article 3 (2012).

5 Lynn A. Stout, Corporate Entities: Their Ownership, Control, and Purpose, Cornell Law School research paper $\mathrm{n}^{\circ} 16-38$ (2017). See also Stephen Bottomley, The Constitutional Corporation Rethinking Corporate Governance, Aldershot: Asgate (2007), p. 27.

6 Ronald H. Coase, Saving Economics from the Economists, Harvard Business Review (December) p. 36 (2012). 
accounting information about its activities. But using corporate accounting as the instrument to determine whether firm management translates into value creation, and as a proxy for the information system required to operate a firm, leads to the generation of considerable amounts of negative externalities. As an organization, the firm differs from its legal structure and from the discrete contractual exchanges occurring via its corporate and contractual structure. A set of accounting norms and standards is required to deal with the externalities it otherwise generates if one relies only on the financial accountability of its corporate structure. Although substance usually prevails over form in accounting, the accounting information provided by economic productive organizations - firms/enterprises - is based on corporate accounting. It is based on the accounting treatment of the legal transactions to which the corporation(s) used to legally structure the firm is(are) party to. Concentrating on the evidencing of the creation of profits and losses taking as a base the preservation of financial capital only leads to the erosion of the other forms of capital used in the management of the firm, such as certain environmental assets, the use of which is not properly accounted for. Treating these forms of capital as deserving equal protection as financial capital can considerably enrich classical accounting and address much of the negative externalities issue.

In this article, I will concentrate on the issue of climate change. We are left with a limited amount of $\mathrm{CO}_{2}$ to emit to reach any given global warming level. To contain global temperature increases at $1.5^{\circ} \mathrm{C}$, the emissions of $\mathrm{CO}_{2}$ need to be reduced drastically ( $-45 \%$ in 2030 compared to their level in 2010) to then reach « carbon neutrality " by 2050, meaning that by then, we will have to stop emitting in the atmosphere more carbon than we take out. In the ideal situation, we will then only have residual emissions (i. e. those of the activities for which there is no substitute) but for which we will create " negative emissions ", i. e. carbon wells absorbing an equivalent amount of $\mathrm{CO}_{2}{ }^{7}$ Then the increase in temperature will stabilize; and temperatures could be reduced if the " negative emissions » (i. e. carbon absorption) become larger than the positive ones.

Nature's $\mathrm{CO}_{2}$ absorption capacity is a form of capital we share. It is not owned by anyone and no one is in a position to present a bill for its use. Falling outside the market/price system and of classical financial accounting, the use of this capital is not properly accounted for. Accordingly, markets cannot discriminate among firms which are environmentally sustainable and those which are not. Corporate accounting concentrates on financial capital. If financial markets are not provided with hard numbers about the environmental costs of firms' operations, they can't process this information and value differently the debt and equity instruments issued by sustainable firms (via their corporate structure) from the debt and equity

7 See the 2018 GIEC Report, available at http://www.ipcc.ch/report/sr15/. 
of unsustainable ones. To preserve nature's $\mathrm{CO}_{2}$ absorption capital, the accounting of economic operations needs to be enriched by the inclusion into the accounting of all the productive organizations (of all the enterprises) of the replacement value of the $\mathrm{CO}_{2}$ used in their operations. One of the instruments to combat climate change would consist in providing financial markets information drawn from an accounting of the firm's operations. The accounting of the firm's operations is relevant information to make effective investment decisions. Today, for example, a corporation can be treated as creating "shareholder value » while emitting massive quantities of $\mathrm{CO}_{2}$ which are not accounted for. This is unsustainable. Mistaking corporate accounting for firm accounting prevents all market participants, including equity owners, from having an understanding of which firms are creating real value and which firms are not.

The model of firm accounting proposed in this article uses financial accounting as a base. But it then integrates the computation of the costs of a firm's activities over the other forms of capital being used in the firm's operations. For example, each ton of $\mathrm{CO}_{2}$ consumed via the firm production process must be compensated by the cost of absorbing one ton of $\mathrm{CO}_{2}$. Only by integrating these costs can one determine whether a firm is environmentally sustainable or not. If a firm is still profitable after the integration of these costs into the accounting of its operations, it is environmentally sustainable. Otherwise, it is not sustainable and survives only because there are negative externalities which are not accounted for in financial accounting.

To understand the need for firm accounting, we need to better understand the institutional structure of market economies and the role of firms in the organization of productive resources. What is important for our purposes is that when a corporation is created to legally structure a firm, there is a first separation of ownership and control: ${ }^{8}$ the corporation owns the productive assets and the shareholders own the shares of stock issued by the corporation to collect the equity capital required for the development of its operations. As a consequence of this first separation of ownership and control, those who are making use of the assets owned by the corporation do not own them. They are corporate executives - not owners - and have access to the assets via corporate law rules. They have possession but not ownership of the productive assets. The

8 The second separation of ownership and control - the one on which Berle and Means concentrated in their book, The Modern Corporation and Private Property (Berle, Adolf A., Jr \& Gardiner Means, The Modern Corporation and Private Property, Transaction Publishers, New Brunswick and London (Ninth printing 2007, 1st edition 1932)) - takes place when managers who do not own a majority of the shares issued by the corporation control its operations. See generally Jean-Philippe Robé, supra, note 4. 
owner is the corporation. Being merely agents of the corporation, which is the owner of the productive assets, corporate executives are bound by the rules set by corporate law determining what they can and can't do with the property owned by the corporation whose property they manage. And the accounting of their activity is measured via the evolution of financial capital compared to the shareholders' contributions: increases are profits; reductions are losses. But the firm and company managers also make use of other forms of capital they do not own. This is the case, in particular, for nature's $\mathrm{CO}_{2}$ absorption capacity. This form of capital is not owned by anyone and its use does not translate into corporate accounting. But it must be taken into account to measure the environmental sustainability of a firm's activities.

\section{Fables}

The current folklore is that in their management of corporate affairs corporate directors and officers are the shareholders' agents and that their sole duty is to maximize short term shareholder value. This false and simplistic idea - spread under the name of " agency theory " - has led to a mess. In fact, nowhere do corporate officers and directors have a legally enforceable duty to maximize short term shareholder value. ${ }^{9}$ And even in the United States, as aptly written by Lynn Stout, "U.S. corporate law does not, and never has, required public corporations to " maximize shareholder value " ... The idea is a fable ". ${ }^{10}$

Many judicial opinions describe the directors' fiduciary duties as being owed " to the corporation and its shareholders ", which implies that the two are not the same. ${ }^{11}$ This is mere logic since the corporation whose estate is being managed by the corporate executives is the owner of the productive assets and the counterparty to the contracts used to legally structure the firm. And it has a legal personality separate from the one of the shareholders. Of course, it is not an individual. ${ }^{12}$ But the legal system treats it as a legal person living its own, separate, autonomous legal life, having very similar rights and duties as those of an individual. The key question under corporate law is what interests those in

9 Lynn A. Stout et al., The Modern Corporation Statement on Company Law (2016), available at https://papers.ssrn.com/sol3/papers.cfm?abstract_id=2848833.

10 Lynn A. Stout, supra, note 3, pp. 23-25.

11 Lynn A. Stout, supra, note 3, p. 28.

12 On a recent debate triggered by the decision Citizens United v. Federal Election Commission, 558 U.S. 310 (2010) of the US Supreme Court, see https://www.degruyter.com/view/j/ael.2011.1. issue-3/issue-files/ael.2011.1.issue-3.xml. 
charge of conducting the corporate affairs must have in mind when they make decisions on behalf of this legal person which, because it is a fictitious legal person, must live via the decisions and actions of real life individuals.

Clearly, directors and officers must have shareholder welfare as a goal. But the board of directors has a strong power to pursue its own vision of what is best for shareholders. And this can include taking into consideration the interests of other stakeholders in the management of the firm. Other interests may be taken into consideration, as long as their integration can be presented as a means of promoting shareholder welfare. ${ }^{13}$ As made very clear under Delaware law by the so-called Craiglist opinion, "when directors decisions are reviewed under the business judgement rule, this Court will not question rational judgments about how promoting non-stockholder interests ... ultimately promote stockholder value. " ${ }^{14}$ Great autonomy is therefore given under corporate law to take into account in the firm's management the various conflicting interests affected. The only cases in which the directors were blamed for pursuing other interests than those of the shareholders are the ones in which they admitted to having put other interests ahead of the shareholders' ${ }^{15}$ But anybody can create a " rational judgment » that caring about the natural environment, the clients and the workers, for example, promotes stockholder value at the end of the day. It is not corporate law which forces directors to endorse a narrow conception of short-term shareholder value. Ideology does. ${ }^{16}$ Corporate officers and directors have a strong belief in the pertinence of " agency theory " because it is supported by most professional economists and the financial press generally. It has no basis in the reality of the legal system but operates as a strong incentive to maximize short-term « shareholder value ». Consequently, the largest owners in our society - corporations -

13 See generally Leo E. Strine Jr., The Dangers of Denial: The Need for a Clear-Eyed Understanding of the Power and Accountability Structure Established by the Delaware General Corporation Law, University of Pennsylvania Law School, Institute for Law and Economics, Research Paper No 15-08 (2015).

14 eBay Domestic Holdings, Inc. v. Newmark, 16 A.3d 1, 34 (Del. Ch. 2010).

15 Leo E. Strine Jr., supra, note 18, p. 23.

16 On this issue, see the varying position of the Business Round Table (BRT). On August 19, 2019, the BRT issued a « statement on the purpose of a corporation » representing a U-turn from its 1997 statement which recommended companies to maximize the wealth of shareholders. This position was itself a reversal from the position held in 1981, in a 14-page booklet entitled Statement on Corporate Responsibility, concluding that « A corporation's responsibilities include how the whole business is conducted every day. It must be a thoughtful institution which rises above the bottom line to consider the impact of its actions on all, from shareholders to the society at large. Its business activities must make social sense just as its social activities must make business sense ». As the astute reader will have noticed, one should read « enterprise » when the BRT speaks of « corporation ». 
are ruled in the short-term interest of only one class of interested parties in firm management: the shareholders. ${ }^{17}$ And this is done in the name of a property right over the corporation which shareholders simply do not have and in the name of corporate law rules which simply do not exist.

\section{Value}

To make things worse, missing the importance of the firm as an economic organization separate from the corporation(s) used to legally structure it has led to an improper accounting of its activities. Directed at the shareholders, lenders and other financial investors, and concentrated on financial capital as the only form of capital worth preserving in firm management, existing accounting rules are unable to effectively account for the full impact of a firm's activities. This is probably the single most important catastrophic consequence of " agency theory ». A real mess.

In his 1970 article, ${ }^{18}$ Milton Friedman based his argument that The Social Responsibility of Business is to increase its Profits on the false idea that shareholders own firms (or corporations - he did not make the distinction) and that managers are their agents. We have seen above and in more details in an earlier article published in this Review why this is mistaken. ${ }^{19}$

But Milton Friedman developed a second line of arguments in the same article in favor of "shareholder value maximization »: a governance model giving the incentive to pursue " shareholder value maximization » only is said to be socially beneficial because it maximizes the wealth created. Once this wealth is maximized, it is then up to political institutions to allocate its use. But neither firms nor their leaders - says Friedman - have anything to do with the allocation of the value created which is a political and not a business decision. We have developed sophisticated democratic political institutions to deal with allocation decisions and it is not up to business people to aim at anything else than maximizing value creation. Otherwise, they act as unelected politicians.

Milton Friedman's theory on the division of labor between « private » and « public » governance was based on the assumption that we live in a perfect

17 For the impact on R\&D policies in the pharmaceutical industry, see William Lazonick, Matt Hopkins, Ken Jacobson, Mustafa Erdem Saking and Öner Tulum, US Pharma's Financialized Business Model, Institute for New Economic Thinking, Working paper $n^{\circ} 60$ (2017).

18 Milton Friedman, The Social Responsibility of Business is to Increase its Profits, The New York Times, September 13, 1970, pp. 32-33, 122 \& 126.

19 Jean-Philippe Robé, supra, note 6. 
normative environment integrating « social » demands and, in particular, internalizing all the " negative externalities » in the cost of producing goods and services (and thus, ultimately, in prices), via mandatory laws, regulations, and taxes. ${ }^{20}$ Unfortunately, we have never lived in such an environment. With Friedman's assumption, governance issues are allocated in such a way that the role of the " private " side of the power system is simplified to the extreme (with the mandate to merely « maximize wealth creation »), the complex issues of correcting the negative externalities and inequalities generated bearing only on the "public " institutions. Of course, the institutions of public governance have never been able to fully address these most complex issues of our society. But the limited mandate given to « private » institutions to simply « maximize wealth » has made the life of public institutions even harder. What was hardly achievable in a world of relatively isolated national economies with an overarching State able to adjust its laws to an evolving economic system just can't be done in the present day globalized economy. We are living today in a global economy where most large firms have a global footprint and operate in the anarchic world of a postWestphalian State System without a global State. In the present context, the assumption that there is a " public » normative system in place to provide the proper normative order so that firms can operate with the simplistic « shareholder value " maximization mandate cannot be made. To " maximize wealth ", the management teams at the helm of large firms decide on the geographical allocation of the resources they control looking worldwide at the pros and cons of the various possible locations. Global firms chose among normative environments and make States compete to provide them with rules appropriate for the conduct of their activities. The contents of States' laws must be adapted for States' territories to remain as competitive places for the location of at least part of the production processes and/or the accounting allocation of value creation in global value chains. In a globalized economy, it is the whole system of allocation of authority, of division of powers and of resources allocation which is affected by the firms' combined decisions. Public authorities, as well as the social and natural environments, bear to an unprecedented extent the consequences of choices made within private firms because globalization is negatively affecting States' internalizing capacities through laws and regulations. It is therefore impossible to assume in such an environment that all negative externalities are perfectly internalized by the political system of mandatory norm creation - as was done by Friedman. Shareholder value can be created without creating wealth, without creating real value.

20 See Yuri Biondi, The Problem of Social Income: the Entity View of the Cathedral, 34 Seattle University Law Review pp. 1025-1047 (2011). 


\section{Denial}

There is even more. Some " negative externalities » are inevitable and involuntary side consequences of almost any activity. But because of the precepts of agency theory and its avatar of shareholder value maximization, other externalities are intentionally produced by firms: externalizing costs on the social or natural environments can translate into corporate profits. As written in 2015 by Leo Strine, the Chief Justice of the Delaware Supreme Court, given existing corporate governance rules,

strong and effective externality regulation is important because the profit-pressure put on corporations by institutional investors is strong. ... stockholders will put pressure on corporate managers to seek as much profit as they can within the range of legally permissible conduct. ${ }^{21}$

In his article entitled The Dangers of Denial, Strine advocates adopting a sober and realistic view of corporate law as it presently exists and draw the consequences:

Under the current legal rules and power structures within corporate law, it is naïve to expect that corporations will not externalize costs when they can. It is naïve to think that they will treat workers the way we would want to be treated. It is naïve to think that corporations will not be tempted to sacrifice long-term value maximizing investments when powerful institutional investors prefer short-term corporate finance gimmicks. ... And it is naïve to think that institutional investors themselves will behave differently if action is not taken to address the incentives that cause their interests to diverge from those of the people whose funds they invest. ... we must recognize that directors are increasingly vulnerable to pressure from activist investors and shareholder groups with short-term objectives, and that this pressure may logically lead to strategies that sacrifice long-term performance for short-term shareholder wealth. ${ }^{22}$

But Strine's pessimistic and sobering view of what is achievable via corporate law then cedes to an unrealistic hope:

if interests such as the environment, workers, and consumers are to be protected, then what is required is a revival of effective externality regulation that gives these interests more effective and timely protection. Critically, this externality regulation must be undertaken on a more global scale to match the regulatory structure to the scope of corporate conduct's impact in a globalizing economy. ${ }^{23}$

This suggestion is akin to the drawing of a plan to escape a desert island on the false assumption that there is a bridge connecting the island to the mainland.

21 Leo E. Strine Jr., supra, note 18, pp. 33-34.

22 Leo E. Strine Jr., supra, note 18, p. 38.

23 Leo E. Strine Jr., supra, note 18, pp. 39-41. 
But there is no bridge. The reality is that the institutions " to match the regulatory structure to the scope of corporate conduct's impact in a globalizing economy " are lacking. The Dangers of Denial are many and it is naïve to think that " a revival of effective externality regulation ... on a more global scale " is accessible. It is simply not possible to expect global regulations (by whom?) to counterbalance the negative effects of the shareholder value ideology. By oversimplifying the issues of corporate governance in a globalizing world, the proponents of shareholder value maximization contribute to the existence of corporate governance systems which systematically convert externalities - costs imposed upon others and the environment, social and natural - into profits. And there is no one to adapt the laws to prevent this from happening.

\section{What Counts}

There is one set of tools which remains to address the shareholder value mess, however, even without a new impetus correcting the Shareholder Value Myth in corporate governance: the rules of accounting. In many cases, an objective accounting of the value created by a firm's activity, considering all the costs and benefits involved, would show that the profits made do not correspond to value creation. But the notion that corporations (and therefore firms, in the mind of those who do not differentiate the two) should only seek to maximize shareholder value leads today to the exploitation of the difference between an accounting of the creation of shareholder value and an accounting of the value created (or destroyed) by the economic activity organized within a firm. ${ }^{24}$ Firing well paid employees in one location to hire lesser paid ones in another country creates "shareholder value ». Closing a regulated plant limiting pollution to open another one in a country in which the activity is unregulated creates "shareholder value ». Reducing one's tax bill by localizing the accounting acknowledgement of value creation in a tax haven creates " shareholder value ». But this can be done only because all the costs and benefits of any management decision are not taken into account in financial accounting. Some States benefit from this state of affairs - as is obvious for tax havens, which live on these gimmicks. But overall, in a world of State competition for the localization of firms' activities, of political failure at the international level and of imperfect regulations, there is usually a difference between the costs and benefits

24 For a critique, see Yuri Biondi, The Pure Logic of Accounting: A Critique of the Fair Value Revolution, Accounting, Economics, and Law: Vol. 1: Iss. 1, Article 7, Available at: https://www. degruyter.com/view/j/ael.2011.1.1/ael.2011.1.1.1018/ael.2011.1.1.1018.xml (2011). 
generated by business decisions and their accounting translation; i. e. there may be creation of " shareholder value » by simply " externalizing costs " (the cost of dismissed employees falling on employees and on the unemployment benefits systems, the cost of environmental pollution bearing on the local or global population, depending on the pollution at stake, or the cost of tax optimization falling on the taxpayers who do not have access to avoidance tricks). The spreading of the doctrine of shareholder value maximization has led to the widespread exploitation of this possibility.

Agency theory thus leads many firms to become organizations producing negative externalities not as an ancillary consequence of their economic activity, as is the case with any economic agent, but as one of their main activities because it is an easy way to make profits. There are, of course, firms producing value and most firms probably produce both value and negative externalities. But shareholder value theory has prevented the development of accounting systems making it possible for the market to select those firms creating only « real value ».

\section{Rules of accounting}

In his institutional analysis of the firm, Ronald Coase always insisted on the importance of accounting, considering that the theory of the accounting system is part of the theory of the firm. ${ }^{25}$ For him, the reason for this was that while:

outside the firm prices and therefore costs are explicit ... and are determined by the operations of the market, within the firm there are [also] explicit costs ... but they are provided by the accounting system. This internal system takes the place of the pricing system of the market. ${ }^{26}$

Since costs are determined within firms by « the accounting system » and not by prices, accounting rules play a key role in the measurement of the performance of the firm and in the organization of its operations. What is accounted for and how is a key determinant of the firms' activities because it determines how the costs of doing business are measured. A key audience of the accounts generated to measure the performance of a firm's activity should therefore be management itself.

When one makes the distinction between "firm " and " corporation ", however, one immediately realizes that, at present, the operations of the firm

25 E. g. Ronald H. Coase, Accounting and the Theory of the Firm, 12 Journal of Accounting and Economics pp. 3-13 (1990), p. 12.

26 Ronald H. Coase, supra, note 30, p. 11. 
are guided by the accounting of the events and contracts taking place at the level of the corporation (or corporations, for firms organized via a group of corporations), that is, at the level of its corporate structure. What is accounted for is that part of the firm's activity which gets translated into legal transactions or events to be accounted for at the corporate level, at the level of the specific legal person(s) used to legally structure the firm. The corporation has issued shares to raise the equity capital and the accounting of its operations concentrates on what affects this financial capital with, as we will see, quite a narrow understanding of what this means.

When the operations of an enterprise are structured using a group of corporations - a group of formally autonomous legal persons operating under a common controlling management structure - the accounting of the operations becomes more complex. Each legal person in the firm's legal structure has its own financials, its own balance sheet and profit and loss statements. These financial statements give a narrow view of the operations of each legal entity. Each legal entity's financials must in principle, at least formally, stand on their feet. It must be so because each legal entity has its own creditors and debtors whose rights and obligations are towards the legal entity only (as a matter of principle) and not against the other legal persons in the group of corporations or the shareholders. But to get a more realistic accounting view of the consolidated operation of the group of corporations as a whole, consolidated accounts have to be prepared, disregarding the existence of the subsidiaries as separate legal persons and treating the group as one single organization for accounting purposes. Anything internal has to be disregarded because it is not the outcome of third party, market transactions. Internal transactions may therefore not have been made at market prices. $^{27}$

To deal with this issue, accountants have developed the idea of treating the group of corporations as an entity (although it is not a legal entity). ${ }^{28}$ But it is for accounting purposes only, as the group of corporations does not exist at law. And this has also created some degree of confusion. Consolidating financial statements only leads to an adjustment of corporate accounting to deal with the fact that some transactions within the group of corporations occur among legal entities under common control. The economic conditions at which they take

27 When available, prices have a superior value in accounting because it takes two contending minds to make a price. See generally Ananias Charles (A. C.) Littleton, Value and Price in Accounting, 4(3) The Accounting Review pp. 147-154 (1929). Within groups of corporations, there are prices but no « contending minds».

28 Yuri Biondi, Arnaldo Canziani \& Thierry Kirat (Eds.), The Firm as an Entity - Implications for economics, accounting and the law, New York: Routledge (2007). 
place may not be reliable and represent what would have happened on the market. To consolidate financial statements, the first issue is to determine the perimeter of the accounting " entity ». It is based on a notion of « control ». The activities of all the legal entities under a common control are treated as the activities of one consolidated concern. The value of the equity stakes in the subsidiaries and sub-subsidiaries, etc. are eliminated (to avoid double accounting of the same economic value) and the operations of all the entities deemed to be under a common control are treated as if they were the operations of one single accounting entity. This way, only transactions with the outside world, with a non-controlled seller or buyer of products or services, are accounted for.

But this is still " corporate accounting » not " firm accounting » since only the transactions or events occurring at the corporate level - at the level of the various legal entities used to structure the firm - within the legal system are accounted for. Only what affects financial capital, with a narrow understanding of what this comprises, is accounted for.

\section{Cooking}

While accountants have not received much help from micro-economists to develop proper firm accounting given the poor state of the economic theory of the firm, accounting as a discipline has not been immune from the prevailing mantra of "shareholder supremacy ». And this has led to a reduced scope of what is accounted for in financial accounting. Initially, accounting rules were developed to answer the needs of merchants, who were merely trading on the market. Their users were the merchants themselves and their agents. ${ }^{29}$ With the advent of the large business corporate industrial firm, a whole series of new issues and interested parties appeared: stockholders, creditors, suppliers, customers, neighbors, the natural environment, and so on. ${ }^{30}$ Stockholders want dividends, creditors want to be repaid, suppliers want to know about the credit of their contracting party, employees want to keep their jobs and prosper, etc. As a consequence of the existence of these various affected interests, generally

29 John Hicks, Capital Controversies: Ancient and Modern, The American Economic Review, Vol. 64, No. 2, Papers and Proceedings of the Eighty-sixth Annual Meeting of the American Economic Association pp. 307-316 (1974), p. 310.

30 Martin Shubik, A Note on Accounting and Economic Theory: Past, Present and Future, 1(1) Accounting, Economics and Law - A Convivium, Article 1, https://doi.org/10.2202/2152-2820. 1012. 
accepted accounting principles (the so-called GAAP) developed in many jurisdictions ${ }^{31}$ and were the result of social processes which required tradeoffs among many parties with differing interests, goals and perceptions. ${ }^{32}$

With globalization and the increased « financialization » of the economy, it became apparent that local irreconcilable accounting rules were an obstacle to " efficient " international financial markets. The International Organization of Securities Commission (IOSCO) lobbied for the establishment of a single and universal international accounting standard, ${ }^{33}$ claiming that inconsistent, nationally imposed accounting standards create obstacles for international investors when reading financial reports. The International Accounting Standards Committee (IASC - the predecessor of the IASB) issued a "Conceptual Framework " in 1989 with the ambition to provide a basis for deciding which various accounting options should be removed or retained in the context of cross-border securities offerings. For our purposes, the point of interest is that in the 1989 Conceptual Framework, the primary users of financial reporting were defined as "present and potential investors, employees, lenders, suppliers and other trade creditors, customers, governments and their agencies and the public » (paragraph 9 of the 1989 Framework). There was an appreciation of the various stakeholders' interests in the content of the accounting information produced and offered. It does not mean that all these various interests were properly taken into account in the setting of the various GAAP accounting rules. The point is that whatever importance was given to nonfinancial stakeholders, they disappeared as targeted « users » of the financials. In the 2010 Framework, the users of accounting information were reduced to include only "investors, lenders and other creditors ». There is no consideration given to the needs of other stakeholders or to the provision of accounting information that is not financial in nature. ${ }^{34}$ As mentioned in paragraph OB 10 of the 2010 IASB Conceptual Framework, "Other parties, such as regulators and members of the public other than investors, lenders and other creditors, may also find general purpose financial information useful. However, these reports are not primarily directed to these other groups." And in the March 2018 Revised Conceptual Framework, the objective of financial reporting remains to "provide

31 They are a local product and there are therefore US GAAP, French GAAP, Italian GAAP, etc. 32 Martin Shubik, supra, note 35, p. 13.

33 Ying Zhang \& Jane Andrew, Financialization and the Conceptual Framework, 25 Critical Perspectives on Accounting pp. 17-26 (2014), p. 19.

34 Craig Deegan, The Accountant Will Have a Central Role in Saving the Planet ... Really? A Reflection on "Green Accounting and Green Eyeshades " Twenty Years Later, 24 Critical Perspectives on Accounting pp. 448-458 (2013), p. 452. 
financial information that is useful to users in making decisions relating to providing resources for the entity ». As we will see in more details hereunder, even if one takes into consideration only the needs of those who provide financial resources for the entity, ${ }^{35}$ this is quite a narrow understanding of the information they require to make proper investment decisions. Under prevailing rules, they are actually getting very misleading information.

Since 2010, the IASB Conceptual Framework has been clearly stating a shareholder primacy perspective with a narrow notion of accountability. ${ }^{36}$ What is accounted for has changed based on agency theory. Agency theory and the shareholder primacy doctrine have translated into a specific form of corporate governance. But this doctrine has also led to market-based accounting regulation led by the International Accounting Standards Board (IASB) whose standards have been implemented into European legislation to rule accounting for listed companies throughout Europe. ${ }^{37}$ They assume that markets and the price system are the most suitable mode of economic exchange and of capital and asset valuation. As a consequence, in particular, the negative externalities generated by the firm activity remain unaccounted for since, by definition, they do not affect prices. And with regard to the determination of the assets affected by the firm's operations, a notion of " control » is applied. In this perspective, many of the resources negatively affected by the firm's activity (air, water, workforce, etc.) cannot be considered as forming part of the entity's assets because they are not « controlled». No one owns air, water or the employees. As a matter of illustration, in a case of soil contamination, if the affected land is owned by the polluter, its value is depreciated in the financials. But if it is not owned by the polluter, there will be a negative accounting impact only to the extent that there is a third party in a position to legally request indemnification. Externalities imposed upon the social and natural environment for which there is no third-party claimant in a position to obtain financial compensation are not accounted for. Only assets legally protected, and primarily owned assets, are being considered. Consequently, as a matter of illustration, an accounting entity destroying all sea creatures and coastal vegetation in its local environment can be financially very successful: the abuse of the resources being considered

35 Being understood that the revised framework only address the needs of financial resource providers, in their decisions about buying, selling or holding equity or debt instruments, providing or settling loans and other forms of credit and voting, or otherwise influencing management's actions.

36 Craig Deegan, supra, note 39, p. 452. See also Bernard Colasse, Comptabilité et vision de l'entreprise - Sur les normes comptables internationales, Le Débat pp. 83-93 (2016).

37 Yuri Biondi, Better Accounting for Corporate Shareholding and Environmental Protection, University of Oslo Faculty of Law Legal Studies, Research Paper n 2014-28 (2014), p. 129. 
outside its « control » is not accounted for. ${ }^{38}$ With such accounting principles, it is possible to create " shareholder value " while not creating any " real value » at all and actually while, in some cases, destroying real value.

Present day international accounting rules are clearly in line with the doctrine of shareholder primacy and are part of the institutional setting which leads to a gigantic worldwide production of negative externalities. Many valuable resources are simply not owned or controlled. And their damage or destruction is thus not accounted for.

\section{Caring}

A viable theory of the firm must be accompanied with, and actually makes it possible to develop, an adequate theory of firm accounting. ${ }^{39}$ With agency theory having biased the accounting of large firms in favor of the acknowledgement of short-term " shareholder value ", accounting is today very misleading and leads to the production of dramatic quantities of negative externalities such as climate change, the issue I will concentrate on in the remainder of this article.

Climate change is due to a production of $\mathrm{CO}_{2}$ ancillary to human activities in excess of nature's capacity to absorb it. Nobody has a property right over nature's ability to absorb $\mathrm{CO}_{2}$ and it is not a " common " as is often argued. It is not something " owned in common ». It is simply not owned, just like a State or an enterprise or Saturn are not owned. There is no legal person having a property right over the resource in a position to transfer the right to own or use it against payment of a price. Nature is not an economic agent selling its production for a price going up and down depending on the demand level. When the resources it produces are being used, no price is being paid. It does not enter economic calculations, be it at the productive or the financial level. To prevent subjective valuation issues, what could be included in the calculations is the cost of restoring the resource, such as planting a forest or building a carbon well using modern technology to absorb $\mathrm{CO}_{2}$ in the atmosphere. But this is not done because no one (no owner) is able to present the bill, and the resources affected are considered to be outside the control of the polluting entity. We are in a typical case of negative externality, and climate change is actually the largest

38 Craig Deegan, supra, note 39, p. 453.

39 Martin Shubik, supra, note 35, p. 5. 
negative externality ever created by the market/price system uncorrected by proper accounting rules.

An enhanced accounting of the operations of the firm, comprising financial, environmental and social metrics would be much more effective to guide decisions about the firm's operations. To correct the damaging impact of improper accounting, the idea has been developed, for example, that « triple bottom line accounting " should be used by management in making decisions. ${ }^{40}$ The idea is that accounting should provide bottom line information about the use of financial capital, but also about the impact of the operations of the firm over the other forms of capital being used and affected by firm management, such as human and natural capital.

There are several approaches in the present literature to promote firm accounting. ${ }^{41}$

The first approach is " ESG reporting for shareholders » which reports on environmental performance insofar as it contributes to an understanding of items in the financial statements. But there is one single bottom line: financial profit for shareholders and ESG reporting (which refers to the reporting of Environmental, Social and Governance data) is just an additional, side information, to supplement the financials which are not modified.

The second approach is "stakeholder reporting ". Corporations report on their financial performance in the financial statements. And they report on their environmental performance in a separate document. The metrics may or may not be expressed in financial terms, and there is no commensurability for the financial statements, nor even among the various metrics used in the environmental report. This method is associated in practice with the Global Reporting Initiative. $^{42}$

The third approach is "stakeholder accounting ». As in the first approach, there is a single bottom line. But the financial accounts are revised to accommodate considerations of sustainability. For example, a liability for environment impact may be recognized even though no such liability would need to be recognized in conventional financial accounting, for example because there is no legal duty to eliminate the negative environmental impact. The financial statements are tweaked to be addressed to a different audience.

40 John Elkington, Cannibals With Forks: The Triple Bottom Line of twenty-first Century Business, Oxford: Capstone (1997).

41 See generally Richard Barker \& Colin Mayer, How Should a "Sustainable Corporation » Account for Natural Capital? Saïd Business School Research Papers, RP-15 (2017), pp. 11-12. 42 https://www.globalreporting.org/Pages/default.aspx 
The fourth approach, the one I endorse, is " sustainability accounting ". This approach is sometimes called " full-cost accounting ». It maintains the existing system of corporate financial accounting but extends it to cover the accounting of the firm's operations. With regards to $\mathrm{CO}_{2}$ production, the concept would be to start from the outcome of corporate financial accounting and to subtract the annual construction cost of a well absorbing the firm's annual $\mathrm{CO}_{2}$ production. Accounting for this cost would demonstrate whether the firm is sustainable or not with respect to its impact on climate change. ${ }^{43}$ The idea is not to reconstruct artificial prices. ${ }^{44}$ On the contrary, the concept is to supplement the price system to account for the cost of using forms of capital which do not translate into the payment of a price. Financial accounting and sustainability accounting are commensurable, both forming part of a single system of accounting, but with two bottom lines which are distinct but also very much connected to each other. The approach does not treat financial statements as inherently useless but seeks to address their limitations when it comes to measuring the sustainability of an organized economic activity - a firm. It takes into account the fact that other forms of capital than financial capital are being used and affected by the production process. Their current default value in financial accounting is zero. Which means that the erosion of these forms of capital, when it occurs because of the production process, is not accounted for. Since they are not on the balance sheet and there is no third party in a position to make enforceable claims that the damage to these forms of capital should be compensated, some other method is to be found to protect them. Financial accounting was simply not designed to incorporate considerations of the social and environmental impact of producing and accounting organizations. ${ }^{45}$

With regards to the natural environment, ${ }^{46}$ negative impacts have always been there. But as long as we were within the planetary boundaries, ${ }^{47}$ as long as nature could absorb these negative impacts, they could be addressed on an ad hoc basis via a series of measures in various legal systems. The situation today is different; survival is at stake for many species of plants and animals and

43 Richard Barker \& Colin Mayer, supra, note 46, pp. 11-12.

44 Yuri Biondi, supra, note 25.

45 Craig Deegan, supra, note 39, p. 450.

46 The preservation of social capital requires a different treatment. See generally Samuel Jubé, Droit social et normalisation comptable, Paris: Librairie générale de droit et de jurisprudence (2011).

47 Steffen Will et al., Planetary Boundaries: Guiding Human Development on a Changing Planet, 347 (6223) Science p. 736 (2015). 
humans and there is no encompassing polity to impose the appropriate rules. Sustainability accounting is the compass to use to drive human activity towards sustainability. It measures, reports and reconciles business activity from both a financial and a sustainability perspective. ${ }^{48}$ While only the so-called " genuine » obligations (those for which there is a legal or constructive obligation resulting from past events) are dealt with in the financial accounts, with full-cost accounting, the accounting of environmental use prevents the presentation of the accounting entity as a cash-generating machine for shareholders and investors when the environment is simultaneously damaged. ${ }^{49}$ Natural capital must be preserved in addition to financial capital and be conceptualized in physical terms, to be offset by the cost of the well physically required to even $\mathrm{CO}_{2}$ production. A goal of physical natural capital maintenance must be applied to the accounting of the reporting entity. By applying a life-cycle approach to products and services, the accounting of the environmental impact of the reporting entity would transcend the fragmentation of the responsibility for environmental impact corporation-by-corporation or country-by-country. For $\mathrm{CO}_{2}$ production, in particular, it is the full impact of the firm which is to be accounted for, irrespective of the location in any subsidiary or supplying entity or country in the value chain. ${ }^{50}$

\section{Saving}

The key point of sustainability accounting is that there is no attempt at giving natural capital any price. None is created by the price system and the attempts to create artificial markets for " rights to pollute », for example, are notorious failures. The European Emission Trading Scheme has been so « efficient " that the prices of the pollution rights have fluctuated widely with a general trend downwards, providing no incentive to reduce pollution. The fact of the matter is that there cannot be any price for natural capital because no one owns it; and no one can. The fact that the price system cannot work to preserve this category of assets is not the outcome of some market failure to be corrected by creating artificial and non-performing " markets ». It is a consequence of what property rights are; and there is none over certain categories of assets such as natural

48 Richard Barker \& Colin Mayer, supra, note 46, p. 12.

49 Yuri Biondi, supra, note 42, p. 132.

50 See also Beate Sjåfjel, Beyond Climate Risk: Integrating Sustainability into the Duties of the Corporate Board, 23 Deakin Law Review pp. 1-22 (2018), p. 6. 
capital and, more specifically, such as nature's $\mathrm{CO}_{2}$ absorption capacity. The fact that some assets, organizations, or what-have-you cannot be priced is not the outcome of « market failure " or « imperfect definition of the property rights ". There are things which cannot be owned - the State, a firm, the ocean, the climate, and so on - but this is not the outcome of any kind of « failure ». The only " failure " is to think that the market can be the sole arbitrator of all values. There are things the market cannot price but which still need to be preserved and valued. And any pricing would be artificial and would likely miss the target by either under- or over-shooting to protect the value considered.

From a sustainability perspective, it is the physical maintenance of the natural resources which is an end in itself. The notion of price is simply irrelevant. What matters is the cost of maintaining the natural resource. An accounting of what can be priced by the market must be supplemented by an accounting of unpriced costs.

Sustainability accounting offers the immense advantage of placing the resources to be preserved outside the realm of economics. ${ }^{51}$ Whereas with financial accounting there is absolute fungibility and unlimited substitutability among the assets and liabilities since only their financial valuation enters the financials, with sustainability accounting, fungibility and substitutability are excluded. It is the physical integrity of the resource which is to be preserved, irrespective of any valuation. For $\mathrm{CO}_{2}$ production, it is the annual cost of a well compensating the amount of $\mathrm{CO}_{2}$ generated by the firm's activities. This is as close an objective figure as one can get, although it will probably depend on the location of the well, which is not an issue given the global nature of the climate change issue. All the negative externalities cannot be properly addressed in this manner because, for example, there are costs which do exist but cannot easily be weighted, such as the destruction of a landscape, or the disappearance of a life-form. But it would be a substantial progress compared to the present rules of accounting.

This suggestion is in line with fundamental rules of accounting, and simply extends their reach. Financial capital is at the heart of financial accounting. ${ }^{52}$ Accounting wise, it is a claim, not a resource. ${ }^{53}$ For accounting purposes, financial capital is not treated as something the accounting entity owns: it is a debt towards shareholders which made it possible to acquire productive assets. $^{54}$ What the accountants call capital is really part of the resources

51 Richard Barker \& Colin Mayer, supra, note 46, p. 13.

52 Richard Barker \& Colin Mayer, supra, note 46, p. 18.

53 Richard Barker \& Colin Mayer, supra, note 46, pp. 19-20.

54 Henry P. Hill, Accounting Principles for the Autonomous Corporate Entity, New York: Quorum Books (1987), p. 8. 
contributed to the corporation and having made it possible to acquire the productive capital required to operate the firm. But eventually, the financial capital must be returned to the shareholders and, in the meantime, its use as a resource has to be paid for. For accounting purposes, it is not owned by the accounting entity, which is a separate concept from the corporation which is owning the capital. Corporate activity affects this value: increases are reported as profits and decreases are reported as losses. Profit measures the excess of the resources generated by a company during a period (income) over the resources it consumes during that same period (expenses). It is, of course, the reverse for losses. No profit can be evidenced to the extent financial capital is being depleted: this would not correspond to an income, but to a reduction of wealth, a consumption of the financial capital contributed by the shareholders.

What cannot happen to financial capital except in cases of fraud, i.e. a consumption of capital treated as an income (which is the essence of a Ponzi scheme, for example ${ }^{55}$ ) does happen with the other forms of capital used by the firm, such as environmental capital. The environmental capital (which is not owned either by the corporation) is being depleted in the production process and is not regenerated by the accounting entity. To prevent such Ponzi schemes in social and environmental capital, the same norm of capital maintenance should apply to the forms of capital other than financial capital being used by accounting entities which they do not own either - because they can't be owned. It is the case, for our purposes, for the use made of nature's $\mathrm{CO}_{2}$ absorption capacity. As advised by the World Business Council for Sustainable Development (WBCSD) in its CEO Guide to the Sustainable Development Goals, ${ }^{56}$

In order to measure, value and report their true value, true cost and true profits, companies need to go beyond financial capital accounting and incorporate natural and social capital as well.

Within the present system, resources for the shareholders can be generated without creating value: there can be increases in shareholder value without

55 In a Ponzi scheme, new contributions of capital by new investors are treated as income and are distributed to former contributors of capital. Capital contributions appear to be compensated; but there is no wealth creation by the entity distributing dividends. There is only depletion of the most recent contributions of capital. This of course can only last as long as there are new contributors of capital.

$56 \mathrm{https} / /$ www.wbcsd.org/Overview/Resources/General/CEO-Guide-to-the-SDGs, p.19. The WBCSD comprises almost 200 world companies working together to accelerate the transition to a sustainable world. See also the SDG Compass which provides guidance for companies on how they can align their strategies as well as measure and manage their contribution to the realization of the Sustainable Development Goals; https://sdgcompass.org/. 
creation of any real value. This is because there are negative externalities which are not accounted for and the cost of correcting them would be higher than the shareholder value created.

With $\mathrm{CO}_{2}$ sustainability accounting, an adjustment is made to financial accounting by accounting for the investments that the reporting entity would need to make to restore the $\mathrm{CO}_{2}$ absorption capacity used in its whole upstream value chain. ${ }^{57}$ This form of natural capital is not anybody's claim: it is not owned. But, like financial capital, it is a form of capital used by the firm which also needs to be preserved and returned. If a company is sustainable (i. e. not only shareholder sustainable), it means it makes enough financial profits to replace the natural capital depleted because of its operations. It has the financial resources for investing in the carbon sinks required to even its $\mathrm{CO}_{2}$ production. A company shown to be unsustainable after the adjustments made to produce sustainability accounts survives only because there are negative externalities which are not accounted for. Sustainable profit is the financial profit a company would make if it internalized its externalities. ${ }^{58}$

This approach has the advantage of dismantling the misleading dichotomies between hard economics and soft ethics, pure finance and corporate generosity, responsibility towards shareholders and corporate social responsibility, hard law and soft law, etc. ${ }^{59}$ Investing in sustainable companies is not ethical, generous or socially responsible; it is just good old-fashioned long-term investing.

\section{Saying}

The sustainability of an accounting entity is a key information to know and report. This information is " relevant », which the IFRS March 2018 Conceptual Framework Project Summary defines as being « capable of making a difference to the decisions made by users " and it is "faithful " in that it "faithfully represent[s] the substance of what it purports to represent ». Investors willing to invest in enterprises which are sustainable in the long-term do not have today the information they need to make the right decisions. ${ }^{60}$ They do not get this " relevant " and " faithful " information. And there are investors urging companies to adopt a long-term perspective who would value this information. Sustainability accounting, which is much more

57 Richard Barker \& Colin Mayer, supra, note 46, p. 26.

58 Richard Barker \& Colin Mayer, supra, note 46, p. 27.

59 Beate Sjåfjel, supra, note 55, p. 13.

60 Beate Sjåfjel, supra, note 55, p. 13. 
"faithful » than mere financial accounting is quite " relevant », at least for a large class of " users », and would allow them discriminating among firms with a future and the rest.

Maybe more importantly, sustainable firms have a clear interest in creating and diffusing this information. They should take the lead in creating a dynamic in which their unsustainable competitors would need to adapt or else disappear. They can demonstrate that they could survive even in a world which would take the natural environment seriously. And if and when restrictive regulations come because of the seriousness of the consequences of our collective lack of foresight, the investors in these firms will fare better than those remaining invested in unsustainable firms. The competitive advantage of firms making it known via hard numbers that they are sustainable would be clear in all the markets in which they operate: the markets for equity, for debt and for the products and services they sell to their clients. Not to mention the labour market to hire the best, responsible, employees.

Board directors have a general duty of loyalty and care. To fulfil their mission, they should find out if the corporation they are overseeing is managing an enterprise which is sustainable or not. A case can be made that this is part of their duties. Here and now. Some even claim that good faith initiatives based on scientific evidence and reasonable economic assumptions should be taken to safeguard a company's continuing prosperity and its sustainability. ${ }^{61}$ But in any case, it is clearly in the interest of at least part of the stockholders to know if the company in which they are invested is being managed in a sustainable manner or not. The reverse, i. e. resisting against the provision of sustainability accounting, is harder to defend. The present and future value of all claims against a company is affected by its sustainability - or lack thereof.

With regard to shareholders, investors, clients, customers, as well as regulators, with access to the information regarding a firm's sustainability or progress towards sustainability, they can adjust their decisions and push for a restoration of the damaged resources or withdraw their investment or business. This is particularly acute for equity investors - shareholders - because it goes against the grain of today's mantra that corporations should maximize shortterm shareholder gains. Apart from any moral consideration (and there is no question that many shareholders do have moral considerations) an equity investor needs to know if the company he is invested in is sustainable or not. Without this information, everything else being equal, two companies can be valued equally when in one, sooner or later, the value of the equity will be

61 See generally Sarah Barker, Directors' Personal Liability for Corporate Inaction on Climate Change, Governance Directions pp. 21-25 (2015), especially p. 25. 
negatively affected while the other one, because it is sustainable, will thrive. With the right information made available, " the subpolitics of investment could be forged into an instrument of power $"{ }^{62}$ A substitute to an unachievable " revival of effective externality regulation ... on a more global scale " ${ }^{63}$ would be in operation.

For downstream net destructions of natural capital, individuals can be made responsible for their own decisions. And States can prohibit or restrict the use of destructives assets, such as excessively polluting cars, and so on. The classical allocation of duties among property rights owners and political institutions works - at least it can.

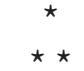

With an enhanced accounting system, we can rely on the most formidable instrument invented to allocate resources among firms: the market. The financial markets are not fulfilling their role today because their operators are not provided with the right information. The market can assess which firms are better at producing shareholder value. But as we know, this concept is different from the concept of real value: firms can create shareholder value while not creating any real value or even while destroying real value. We need firms and their corporate structure to improve the information given to market participants for them to be in a position to identify and promote the firms which are better at producing real value as opposed to mere « shareholder value ». And start cleaning up the mess.

\section{Sources}

Barker, R., \& Mayer, C. (2017). How should a "Sustainable Corporation » account for natural capital? (RP-15). Saïd Business School Research Papers.

Barker, S. (2015). Directors' personal liability for corporate inaction on climate change (pp. 21-25). Governance Directions.

Beck, U., \& Willms, J. (2004). Conversations with Ulrich Beck. Cambridge: Polity Press.

Berle, A. A., Jr., \& Means, G. The modern corporation and private property. New Brunswick and London: Transaction Publishers (Ninth printing 2007, 1st edition 1932).

Biondi, Y. (2011a). The problem of social income: The entity view of the cathedral. Seattle University Law Review, 34, 1025-1047.

62 Ulrich Beck \& Johannes Willms, Conversations with Ulrich Beck, Cambridge: Polity Press (2004), p. 219.

63 As proposed by Leo E. Strine Jr supra, note 18, pp. 39-41. 
Biondi, Y. (2011b). The pure logic of accounting: A critique of the fair value revolution. Accounting, Economics, and Law, 1(1), Article 7, Available at: https://wwwdegruytercom/ view/j/ael.2011.1.1/ael.2011.1.1.1018/ael.2011.1.1.1018.xml

Biondi, Y. (2014). Better accounting for corporate shareholding and environmental protection, University of Oslo Faculty of Law Legal Studies, Research Paper n 2014-28.

Biondi, Y., Canziani, A., \& Kirat, T. (Eds.). (2007). The firm as an entity - implications for economics, accounting and the law. New York: Routledge.

Bottomley, S. (2007). The constitutional corporation - rethinking corporate governance. Aldershot: Asgate.

Coase, R. H. (1990). Accounting and the theory of the firm. Journal of Accounting and Economics, 12, 3-13, 11.

Coase, R. H. (2012, December). Saving economics from the economists (p. 36). Harvard Business Review.

Colasse, B. (2016). Comptabilité et vision de l'entreprise - Sur les normes comptables internationales (pp. 83-93). Le Débat 15(2), 207-233.

Deakin, S. (2017). Tony Lawson's theory of the corporation: Towards a social ontology of law. Cambridge Journal of Economics, 41, 1505-1523.

Deakin, S., Gindis, D., Hodgson, G. M., Huang, K., \& Pistor, K. (2017). Legal institutionalism: Capitalism and the constitutive role of law. Journal of Comparative Economics, 45, 188-200.

Deegan, C. (2013). The accountant will have a central role in saving the planet ... really? A reflection on "Green Accounting and Green Eyeshades » twenty years later. Critical Perspectives on Accounting, 24, 448-458.

Elkington, J. (1997). Cannibals with forks: The triple bottom line of twenty-first century business. Oxford: Capstone.

Friedman, M. (1970, September 13). The social responsibility of business is to increase its profits, The New York Times, 32-33, 122 \& 126.

Hicks, J. (1974). Capital controversies: Ancient and modern, The American Economic Review, Vol. 64, No. 2, Papers and Proceedings of the Eighty-sixth Annual Meeting of the American Economic Association, 307-316.

Hill, H. P. (1987). Accounting principles for the autonomous corporate entity. New York: Quorum Books.

Hodgson, G. M. (2018). Taxonomic definitions in social sciences, with firms, markets and institutions as case studies. Journal of Institutional Economics, 15(2), 207-233.

Jubé, S. (2011). Droit social et normalisation comptable. Paris: Librairie générale de droit et de jurisprudence.

Lazonick, W., Hopkins, M., Jacobson, K., Saking, M. E., \& Tulum, Ö. (2017). US pharma's financialized business model, Institute for New Economic Thinking, Working paper $\mathrm{n}^{\circ} 60$.

Littleton, A. C. (1929). Value and price in accounting. The Accounting Review, 4(3), 147-154.

Palan, R. (2003, 2006). The offshore world - sovereign markets, virtual places and nomad millionaires. Ithaca: Cornell University Press.

Robé, J.-P. (2011). The legal structure of the firm. Accounting, Economics, and Law, 1(1) Article 5, ISSN (Online), 2152-2820. doi:10.2202/2152-2820.1001

Robé, J.-P. (2012). Being done with Milton Friedman. Accounting, Economics, and Law, 2(2), Article 3. doi:10.1515/2152-2820.1047

Shubik, M. (2011). A note on accounting and economic theory: Past, present and future. 1(1). doi:10.2202/2152-2820.1012 
Sjåfjel, B. (2018). Beyond climate risk: Integrating sustainability into the duties of the corporate board. Deakin Law Review, 23, 1-22.

Steffen W., Richardson K., Rockström J., Cornell S. E., Fetzer I., Bennett E. M., ... de Wit Cynthia A. (2015). Planetary boundaries: Guiding human development on a changing planet. Science, 347(6223), 736.

Stout, L. A. (2012). The shareholder value myth - how putting shareholders first harms investors, corporations and the public. San Francisco: BK Business Books.

Stout L. A., Robé J.-P., Ireland P., Deakin S., Greenfield K., Johnston A., ... Dignam A. J. (2016). The modern corporation statement on company law. Available at: https://papers.ssrn. com/sol3/papers.cfm?abstract_id=2848833.

Stout, L. A. (2017). Corporate entities: Their ownership, control, and purpose, Cornell Law School research paper $\mathrm{n}^{\circ} 16-38$.

Strine Jr., L. E. (2015). The dangers of Denial: The need for a clear-eyed understanding of the power and accountability structure established by the delaware general corporation law, University of Pennsylvania Law School, Institute for Law and Economics, Research Paper NO. 15-08.

Tirole, J. (2006). The theory of corporate finance. Princeton: Princeton University Press.

Zhang, Y., \& Andrew, J. (2014). Financialization and the conceptual framework. Critical Perspectives on Accounting, 25, 17-26.

Article note: This article will appear in a slightly different form in a book entitled « The World Power System - The Corporate Reconfiguration of Property Rights and the Challenge to the State System ». 